\title{
Japan's unpopular mental health laws to be revised at last
}

Tokyo

JAPAN's mental health laws are about to undergo their first revision in 22 years. The reforms, contained in a bill to be submitted to the Diet by mid-March, are a response to severe international criticism of Japan's mental health system.

The sorry state of Japan's mental hospitals first caught worldwide attention in 1984 when a scandal erupted at Utsunomiya Hospital. It was reported in the press that violence and confinement were regularly used to subdue patients, patients were forced to labour at a deep-freeze food factory owned by the hospital superintendent's family, others were made to act as assistant nurses and give injections to fellow patients. And, worst of all, two patients were allegedly beaten to death.

Representatives of the International Commission of Jurists (ICJ) and the International Commission of Health Professionals (ICHP) visited Japan on a factfinding mission in May 1985 at the invitation of lawyer Etsuro Totsuka, one of Japan's foremost campaigners for mental health reform. A 94-page report released by the mission in September last year concluded that "the present structure and function of Japanese mental health services create conditions which are conducive to inappropriate forms of care and serious human rights violations". The major areas of concern identified by the mission were a lack of legal protection for patients, and a system of care characterized by a preponderance of long-term institutional treatment with little community treatment or rehabilitation. The commission recommended that an independent body be set up to review involuntary hospitalizations.

While the numbers of mental inpatients in countries such as Britain and the United States have been falling, Japan's inpatient population has grown more than twentyfold over the past 30 years to 340,000 , about 80 per cent of them involuntary admissions. Most of those confined against their will were committed by "consent" (doinyuin) under section 33 of the present mental health act. Consent is obtained not from the patient but from the family or a legal guardian. As there is still a considerable social stigma associated with mental illness in Japan, families are often only too willing to commit their mentally ill relatives. The only medical opinion required for such confinement is that of the superintendent of the hospital.

The main revisions to the law instituted by the Health and Welfare Ministry are: voluntary admissions will be encouraged but all of the clauses for compulsory admission will be retained in modified form (under the old law there was no clause for voluntary admission); prefectural review councils will be set up to hear patient's complaints and to screen involuntary admissions; local bodies and welfare organizations are urged to establish rehabilitation centres.

Etsuro Totsuka welcomes the revisions but still sees serious defects. "Consent hospitalization" is retained under a new name "protective hospitalization", the only change being that the medical opinion of a "designated doctor" rather than the hospital superintendent must be sought before committal and the patient's case will be periodically reviewed by the prefectural review council. But ministry officials expect that the designated doctor will come from the hospital in which the patient is to be hospitalized. Totsuka also questions the independence of a prefectural review council of three designated doctors, one lawyer, and one "man of knowledge and experience".

Professor Haruo Akimoto, former director of Tokyo Metropolitan Matsuzawa Hospital in Japan, also expresses doubts about the independence of the review council and he advocates inclusion of lay organizations such as the National Federation of Families of the Mentally Ill in Japan; Totsuka favours the British system of Mental Health Review Tribunals which consist of one doctor, one lawyer and one lay person.

A third serious defect is the lack of an equality clause to eliminate discrimination against the mentally handicapped. At present mental patients in Japan are barred from entering art museums or swimming pools; they cannot take up certain professions, such as hairdressing; and general rehabilitation and welfare services are not available to psychiatric patients. The Health and Welfare Ministry has asked the various ministries concerned to eliminate such discrimination, but no legislative action has been taken.

Finally, although there is a clause in the law calling for free, uncensored communication by patients with the outside world by letter, telephones are not mentioned. And there are no provisions in the law for meeting lawyers or independent doctors.

Both Totsuka and Akimoto welcome the clause calling for improved rehabilitation services. But they question whether the words will be backed up with government money. Akimoto hopes that "the new law is not just a gesture by the government intended to appease international criticism but that it will really assist rehabilitation and independence of the mentally ill". What is needed, he says, is reform of the hospitals, not just reform of the law.

David Swinbanks
NASA science head

\section{Washington}

LENNARD Fisk has been named to succeed Burton Edelson as head of the office of space science and applications at the National Aeronautics and Space Administration. Fisk is at present a professor of physics at the University of New Hampshire in Durham. Until his appointment was announced last month, he was chairman of the space science working group of the American Association of Universities and chairman of the National Academy of Sciences committee on solar and space physics.

Fisk's selection has been warmly received in the academic community. Thomas Donahue, chairman of the National Academy of Sciences space science board, calls Fisk "a card-carrying scientist" who will be able to work well with the space science community. His appointment takes effect on 6 April.

J.P.

\section{Death of Steve Prentis}

\section{London}

Steve Prentis, who died in a car crash on 27 February, had only recently become director of the Banbury Center and director of publications at the Cold Spring Harbor Laboratory, Long Island, where he was to be the editor of the journal Genes and Development, which was launched last week. Before moving to the United States, he had been based at the Cambridge offices of Elsevier in the United Kingdom, where he was initially editor of Trends in Biochemical Sciences, and then founding editor in turn of Trends in Biotechnology and Trends in Genetics. A second edition of his widely praised book, Biotechnology: A New Industrial Revolution has just been published.

P.N.

\section{Plea for return of exiles London}

THE University of Kabul has issued an appeal to former employees who have fled from Afghanistan to return home. Their jobs are still open, the appeal said, their reputations are still held in respect, the laboratories and libraries are awaiting them. The university will put at their disposal "every available opportunity" to prepare themselves for their return to teaching and to help them to carry out "better research".

The appeal, broadcast by Kabul radio, was presented as part of the current policy of national reconciliation. But the university also confessed its need of the emigrés. The lecturers now working there do not, it said, have the "knowledge, experience and energy" of those who went abroad. In fact, according to the Refugee Studies Programme of the University of Oxford, very few Afghan emigré academics have managed to find professional posts abroad, and most are still living in refugee camps. V.R. 